\title{
Consumer Storytelling of Brand Archetypal Enactments
}

Karlan M. Muniz, Pontifícia Universidade Católica do Paraná, Brazil

Arch G. Woodside, Boston College

Suresh Sood, University of Technology, Sydney

Submission: September 2012

Revision: January 2014

Second Revision: August 2014

Revision: September 2014

Acceptance: September 2014

Citation: Muniz, K.M. Woodside, A.G. and Sood, S. (2015). Consumer storytelling of brand archetypal enactments. Int. J. Tourism Anthropology, Vol. 4, No. 1, pp.67-88. 


\section{Consumer Storytelling of Brand Archetypal Enactments}

Karlan M. Muniz

Pontifícia Universidade Católica do Paraná, Brazil

Rua Imaculada Conceição, 1155

Bloco Acadêmico - Sala 103B - $1^{\circ}$ Andar

Prado Velho - Curitiba, PR, CEP: 80215-901

FAX: (41) 3271-1476

e-mail: karlanmuniz@gmail.com

Arch G. Woodside

Boston College

140 Commonwealth Avenue

Department of Marketing, Fulton Hall 450

Chestnut Hill, MA 02467-3809

FAX: 617552 6677e-mail: arch.woodside@bc.edu

Suresh Sood

University of Technology, Sydney

Academic Programs Development Coordinator

City Campus, 15 Broadway

Ultimo NSW 2007

e-mail: suresh.sood@uts.edu.au

Note: the first author is grateful to the CAPES (a Brazilian foundation) for the granted scholarship allowing him to participate of this research. The authors are grateful for the review commentaries by the blind reviewers and by Drew Martin, University of Hawaii, to early drafts of this article. Send correspondence to Arch G. Woodside, corresponding author, Tel.: +1 617552 3069; fax: +1 6175526677 . 


\title{
Consumer Storytelling of Brand Archetypal Enactments
}

\begin{abstract}
The study here probes the perspective that consumers use certain brands as actors that play roles in the consumers' lives and that help consumers as protagonists to enact roles that give them the feelings of achievement, well-being, and/or emotional excitement. The method enables the uncovering of archetypes as unconscious forces that drive consumers to specific actions implicitly and to a less extent, explicitly. The study employs two techniques: degrees-of-freedom-analysis (DFA) to test whether or not consumer stories fit a given archetypal theme and visual narrative art (VNA) to confirm whether or not consumer's own stories enact a specific archetype and how such enactments are done. This study offers an alternative for survey auditing consumer-brand relationships; the study here describes and explains the importance of narratives in consumer behavior and the use of archetypes as universal themes that aid understanding of brand-consumer relationships. The study describes DFA and VNA with two examples of the use of these analytics.
\end{abstract}

Keywords: archetype; consumer-brand relationship; consumer narrative; degrees-of-freedom analysis; visual narrative art 


\section{Biographical notes:}

Karlan Muniz is a Brazilian PhD student in Business Management at Pontifícia Universidade Católica do Paraná (Brazil). Graduated (BSc) in Communication, his current research is about brand narrative and its impact on consumer behavior.

Arch G. Woodside is a member and Fellow of the Royal Society of Canada, American Psychological Association, Association for Psychological Science, Society for Marketing Advances, the International Academy for the Study of Tourism, and the Global Academy of Innovation and Knowledge. His 400+ research journal articles appear in 42 different psychology, management, marketing, and tourism journals. He is the Editor in Chief of the Journal of Business Research.

Suresh Sood holds a MBA and $\mathrm{PhD}$ in the study of thick description brand stories found online from University of Technology, Sydney (UTS). He is a past visiting fellow, Faculty of Business, UTS, part time lecturer and Co-director/founder of the Complex Systems Research Centre. His research drives development of software for automated detection of archetype consumer interactions with brands in social media stories. He conducts the most popular social media marketing practice courses in the southern hemisphere with over 5,000 executives and students attending his courses online and offline. 


\section{CONSUMER STORYTELLING OF BRAND ARCHETYPAL ENACTMENTS}

\section{Introduction}

The growing consumer-brand relationship literature focuses on describing interpersonal relationships for understanding the multiple forms of relationships between consumers and brands (Aggarwal, 2004; Fournier, 1998, 2009). Researchers emphasize the roles of the consumer-brand relationship as a provider of meaning for people who engage in these relationships (Allen, Fournier, \& Miller, 2008; Fournier, 2009). The consumer cocreates the brand's meaning and views herself and the brand as taking part in a narrative (Allen, Fournier, \& Miller, 2008; Woodside, Sood, \& Miller, 2008); the actors in the narrative may evaluate the storyline narrative not only rationally but as a way of feeling a sense of achievement, well-being, and/or excitement.

If relationships with brands are means for the consumer to reach certain psychological end-state for herself (Fournier, 1998; 2009), brands serve as tools for the consumer to construct a self-concept and express self to others (Escalas \& Bettman, 2005; Keller, 1993). Psychological theory offers a platform that includes archetypal figures. Some studies in the marketing literature describes archetypes and myths as allegories supporting the construction of brand-consumer relationship (Dichter, 1960; Holt, 2004; Veen, 1994; Woodside, Sood, \& Miller 2008; Zaltman, 2003) and the evidence suggests this theoretical foundation is successful in studies by marketing professionals (Mark \& Pearson, 2001; Vincent, 2002; Wertime, 2002).

This study explores the possibility of investigating consumer-brand relationships using the platform of archetypal themes, putting forward techniques that can identify the position of brands in the life story of a consumer broadly and objectively, thereby exploring not only the spontaneous story told by the consumer but also the brand's position and meaning within what the consumer wishes to expose as her life, both in general and on the 
spur of the moment. This article includes a brief explanation of the function of archetypes in human behavior and discusses the importance of narratives in human behavior and the materialization of archetypal themes. Degrees-of-freedom (DFA) and visual narrative art (VNA) methods identify the archetypes adopted and brands' roles in consumers' narrative projections. Two examples taken from blogs illustrate how brands of services, products, people, and places support the experience of these roles by the consumer. Finally, the discussion concludes with theoretical and managerial implications of this anthropological research.

\section{Influence of archetypes on human behavior and consumption}

Jung (1959) proposes that accumulated experiences in past generations influence who we are today. His contribution to psychology includes the concepts of collective unconscious and archetypes, the themes that constitute deposits of memories that accompany and influence how human beings live today (Jung, 1959). According to Jung (1959), myths and fairytales are forms that archetypes receive, serving as a vehicle or discourse that carries coded meaning (Zehnder \& Calvert, 2004). These stories represent a model present in the human mind, maps of the psyche that include valid and emotionally realistic stories, even when portrayed as fantastic and impossible events (Vogler, 2007).

Although unobservable (Faber \& Mayer, 2009), archetypes are part of the representations used by societies that, without communication and shared rituals, myths and other archetypal representations, would not exist (Hall, 1997). Therefore, themes and characters are evoked in rites of passage and in entertainment shared by a number of cultures, and internally impregnated in a human being's reflection of himself. Jung suggests that archetypes reflect different aspects of the human mind and personalities divide into archetypal characters to enable humans to play out the drama of their lives (Vogler, 2007).

Students of psychology focus on human beings embarking on psychological journeys to understand themselves through myths (Pearson, 1998) or constructing own myths 
(McAdams, 1993). According to Campbell (1988), people seek experiences to feel alive, and myths guide these experiences of meaning, experience of life. Myths provide harmony and a sense of achievement. Myths also explain why so many stories have central themes that are repeated without losing their appeal. The mythology that Campbell (1968) describes, based on the rationale behind Jung's archetypes, deals with the most essential human questions, making mythology a tool for understanding catharses that humans experience.

Brands are "modern myths" and the rise of a brand "icon" can occur- described as the much sought after highest level of differentiation in the market (Holt, 2003; Vincent, 2002). The consumer-brand relationship also includes unconscious processes, in addition to cognitive evaluations and affective responses (Zaltman, 2003). Consumers tell stories that connect to the collective unconscious, bringing personal meanings and fit into cultural contexts (Hirschman, 2010). Consumer stories serve as raw material for identifying archetypal patterns and investigating the consumer-brand relationship model. Most thinking is done subconsciously and retrieved as metaphors (Zaltman, 2003). Consumer memories are organized as stories (Shank, 1995). The analytics here serve to release these stories to enable researchers to drill down to the unconscious memory. Visual narrative art (VNA) uncovers and visualizes the story stored in memories retrieved by consumers.

Archetypes operate as a universal language. Archetypes are forces to which people aspire to experience and repeat unconsciously and consciously - a way of seeking pleasure and achievement (Woodside, Sood, \& Miller, 2008). Some brand and marketing executives adopt the platform of archetypes to enact brands as role-players in archetypes (Solomon, 2013). Therefore, monitoring archetypal patterns in consumer narratives helps to improve understanding of the roles brands enact or how bands can potentially fit into consumers' lives. In order to access these patterns, analysis need to examine the verbal vehicles consumers use to transmit this archetypal theme: their own stories. 


\section{Consumer stories as raw material for identifying archetypal patterns and investigating} the consumer-brand relationship model

Human knowledge is based on stories with a basis in past experiences and that new experiences are interpreted by making use of these stories (Schank, 1995; Schank and Abelson, 2003). Individuals transmit these memories in a variety of ways in forming the “remembered” self (Bruner, 2004; Schank \& Abelson, 1995). Escalas and Bettman (2000) describe consumers as builders of stories. The major focus of stories makes sense when consumers state who they are and what they consume. People mentally construct their biography in narratives, in a constant process of interpretation and reinterpretation of experiences (Bruner, 2004).

The study here uses spontaneous stories from consumers as a starting point for auditing a brand role enactment, with a view to identifying its function as a support for the consumer to experience a feeling of achievements that is embedded in archetypes. In the consumer's eyes, the narrative is the cognitive process that verbalizes meanings to events by identifying them as part of a plot, contributing to the organization and construction of his own self (Polkinghorne, 1991).

According to Polkinghorne (1991), the narrative structure makes the actions of friends and contacts, individuals and groups, and governments and institutions more significant and coherent, more specifically providing meaning and identity to the individual himself. In addition to seeing their own identity in terms of a list of attributes, such as height, beauty, capacity for fulfillment, these attributes associate in the memory to key episodes which, when put in order, form a story (Ahuvia, 2005; Belk, 1988).

Connecting, on the one hand, myths and archetypes as general themes with the power to repeat themselves both in groups and in the individual unconscious and, on the other, the phenomenon of the narrative as a vehicle for constructing or strengthening a self-identity, there arises the possibility of mapping how the consumer positions the brand (and how he 
sees it) at that moment (or in that episode) of his life through mapping the archetypes in his discourse. As many templates of the consumer-brand relationship are available and a variety of such relationships occur (Fournier, 2009; Fournier, Avery, \& Alvarez, 2012), the way that a brand "takes part" in a consumer's story when he or she organizes own thoughts can say a great deal about the nuances of this relationship. A recent study by Miller, Fournier, and Allen (2012, p.48) shows that the same brand can be mentioned in different relationship scenarios according to individual consumers and that "brand selection is largely idiosyncratic and dependent on respondents' experiences with brands".

Faced with this challenge (to find an archetypal theme and map the position of the brand in the story) the degrees-of-freedom analysis (DFA) and visual narrative art (VNA) are tools map for interpreting brand-consumer relationships from the point of view of the consumer as the narrator of self and brand role enactments.

\section{The DFA method for testing archetypal themes in the story told by the consumer}

Campbell (1975) suggests a "pattern-matching" procedure between the theoretical propositions and observations in a set of data. DFA compares propositions or ingredients from a separate theory or a "theory-in-use" to check how well the case under analysis matches one or more competing theory. As Campbell (1975) states, keeping a record of all theories considered in the puzzle-solving process is important, and this method represents the degrees-of-freedom from multiple implications and can be useful for computing a box score of hits and misses to test which theory is relevant to a specific case. The phenomena in the consumer behavior field are complex. To better describe or investigate nuances of the behavior described in a story, for example, the DFA can be a useful tool because of its flexibility.

The prediction matrix is central to DFA (Campbell, 1975; Woodside, 2010). Based on the theory, and in order to be confirmed or disconfirmed by case data, the prediction matrix is organized into a list of statements (objective questions about the case) and the content of each 
statement predict that a theory is either confirmed $(\mathrm{Y})$, not-confirmed $(\mathrm{N})$, not possible to confirm, or partially confirmed (P). One or several judges evaluate the data to tally the theory box-score findings.

In the context of consumer stories that contain brands, the study includes creating a matrix for each archetype, based on the theory or literature that is available, and this instrument is used to confirm the dominance of one archetypal theme within the story told by the consumer.

\section{The VNA method for mapping and "visualizing" the story told by the consumer}

In the field of marketing, some researchers defend the idea that consumers are incapable of reporting all relevant causes for their actions and that some memories, emotions, and other cognitive processes lie in the unconscious (Zaltman, 2003), and that a multiplemethods approach is necessary to explain this amount of information (Woodside, 2004).

VNA utilizes one or more types of illustrations (paintings, sculpture, photographs, physical movements, film, or other media beyond verbal reporting) that create a story formed by scenes or episodes in which people, animals, objects, and symbols interact as the narrative unfolds (Megehee \& Woodside, 2010). Approaches in the literature and which also deal with pictures to unveil metaphors or meanings embedded in consumption, such as the Zaltman metaphor elicitation technique (ZMET; Christensen \& Olson, 2002) and the forced metaphor elicitation technique (FMET; Woodside, 2008), differ from the VNA because the former brings meaning-to-light, while VNA, in the hands of a competent researcher, can serve to glean and map what is unapparent in the story that a consumer presents (Megehee \& Spake, 2012).

The use of VNA in research is based on the theory of dual processing accounts of reasoning, emotions, judgment, and social recognition (Evans, 2008), where there occurs on the one hand an unconscious, holistic, and associative thought processes that are common to all animals irrespective of intelligence, while on the other there is also a parallel process that 
is conscious, analytical, based on rules, and solely human, pertaining to intelligence and limited to the capacity of a working memory. As individuals use both types of mental processing, researchers can make use of reports that reflect on the two processes, creating verbal reports of the concepts and results, but also VNAs enhance data interpretation (Megehee \& Woodside, 2010). Therefore, the VNA method is used with a view to reproducing the story described by the consumer visually, increasing the accuracy of the analysis and helping to find different insights concerning how archetypes are enacted in consumer stories and what role the brand plays in this story. This procedure supports and increases possible interpretations concerning the role of brands and archetypes enactments by consumers during their consumption and life experiences.

Applying DFA and VNA provides a unique blending of traditional (empiricalpositivistic) and non-traditional (e.g., existential phenomenological and psychoanalytical) research methods (Park, 2012). Possibly the blending qualifies for applying Park's (2012, p. 471) metric for innovativeness, "A manuscript is highly novel and interesting if and when readers of that manuscript would want to instantly pick up their phones to share their thoughts with friends...".

\section{Method}

Two stories by consumers were collected from blogs on the internet. Both stories involve brands of products, services, people or places (see Appendices 1 and 3 for details). The stories were analyzed employing the DFA method, using an instrument created for each archetype. Thirteen archetypal themes were used, all of which had previously been classified in the literature (Mark \& Pearson, 2001).

Two themes appear. The first consumer story is compatible with the creator archetype. The story describes a professional tailor, the Versace brand, and the singer David Bowie. The second narrative involves the sage archetype and includes the image of a city (Beijing). Both cases delineate the effects that these elements have on the consumer and the possibility that 
he can experience the archetype with the support of brands and other characters. A brief description follows of the archetype and its presence in the consumers' behavior. Analyses of the stories of the consumers follow based on the correspondence test between theory and case by the DFA method and how the story appears using VNA. The discussion concludes with information about how the brand fits into the plot, enabling an analysis of the consumerbrand relationship.

Applications of archetypal theory to consumer associations with brands serve to complement and extend consumer-brand identity theory (Aaker, 1997; Allison \& Uhl, 1964; Belk, 1988; Brasel \& Gips, 2011; Dijksterhuis, Smith, Van Baaren, \&Wigboldus, 2005). Unconscious processing goes deeper than identification to include enactments of primal forces in which consumers use brands as props, partners, and/or mentors to enable transformations, catharses, and what Aristotle refers to as "proper pleasure" from postpsychological-journey storytelling (Woodside, et al. 2008).

The consumer-brand archetypal theory also deepens Kervyn, Fisk, and Malone's (2012) "brands as intentional agents framework" whereby consumers have relationships with brands that resemble relations between people. Kervyn's et al. (2012, p. 166) perspective that "consumers perceive brands in the same way they perceive people" and their focus on abilityintentionality configurations with respect to consumer-brand relationships is insufficient. Much like Clark Kent transforming into Superman via a telephone booth, the everyday housewife transforms into a Siren by buying and modeling a Versace coat front of her "man of the moment" (Woodside et al. 2008), brands enable consumer transformations to achieve enactments of mostly unconscious processes and behavioral acts that result in experiencing primal forces - psychological journeys that frequently include catharses, joy, and sometimes disastrous outcomes.

EXAMPLE: THE CREATOR ARCHETYPE 
The creator is a common force in stories from any time and place around the world (Hamilton, 1942); characters are capable of altering people's lives for both better and worse. People have a great deal of respect for characters that are called creators. In many cultures, the work of creation by a god explains the nature of human beings and these stories serve as a guide for people and represent spiritual strength (Hamilton, 1942). Therefore, the creator links to the divine (Campbell, 1968) and connects with immortality. "[W]hat we are looking for in these creation stories is a way of experiencing the world that will open to us the transcendent that informs it, and at the same time forms ourselves within it" (Campbell, 1988, p. 52). According to Campbell (1988), people unconsciously desire such experiences. Additional studies on archetype influences on consumer behavior (Woodside, Sood, \& Miller, 2008; Woodside, Megehee, \& Sood, 2011), emphasize that the theme of the creator can be experienced by the consumer in her everyday life. From the gifted cook to the entrepreneur capable of developing a successful new business, human beings admire, mirror themselves on and wish to experience the creator's role.

The creator archetype is viewable as an artist or entrepreneur capable of exploring the human imagination and inspiring people (Mark \& Pearson, 2001). The creator's gift is almost a divine blessing or even a simulation of divine power (Wertime, 2002). Campbell (1968) states that the hero, which is in all of us, assumes a creative posture when the hero leaves the world in which she lives, comes into contact with a source of power and returns, refreshed and ready to give history a new spin.

Drawing a parallel between myth and its application to the consumer's environment, the creator alters destiny with her invention or achievement (Hamilton, 1942). The consumer, through the brands she consumes, expresses herself, and alters her destiny (Mark \& Pearson, 2001). Creativity is a valued resource among people and brands in a competitive environment. Be the goal to win a promotion, to get a boyfriend, or to stand out from commercial rivals, the concept of something new, with a personal touch and if possible with 
the benefit or innovation or originality, can impact and sell the desired image to people and companies.

According to Mark and Pearson (2001), marketing dreams and fantasies offer flashes of inspiration to consumers, who imitatively assume the role of creator, adopting what they see as something valuable, original and creative; or they may adopt the brands that seek to express their view or style, using the brand as a tool for this purpose; or they may be inspired by the philosophy of the brand as a platform with personal value or something that can influence culture and society (Mark \& Pearson, 2001). Brands such as Apple include these three dimensions when the brand is related to designers that undertake professional graphic projects, when it is successful with lay consumers of technology who see in the brand the sign of a revolution, the creation of something new and changes in people's lives.

\section{A CASE STUDY OF THE CREATOR ARCHETYPE}

Appendix 1 describes a story in which it is possible to visualize the components of the creator archetype. This text represents the emic interpretation and contains an entire blog story about a consumer who discovers a tailor with a special talent or power who makes highquality clothes with a personalized style. The clothes made by the tailor reflect sophisticated brands and give status to the consumer who wears them. Seeking to test the story in the prism of the creator archetype, Appendix 2 is a prediction matrix of the creator archetype, developed using the literature on the archetype (Campbell, 1988; Hamilton, 1942; Mark \& Pearson, 2001; Wertime, 2002). Evidence of the presence of the archetype is narrative available on the internet. All sixteen statements in the "Archetypal Story Pattern Instrument" (ASPI) of the Creator (Appendix 2) match with characteristics of the Creator.

\section{Decoding the First Story}

The narrative begins with the consumer surprised with the suit that his friend is wearing and an even greater surprise when his friend tells him how much he paid for the clothes. Surprise is one characteristic of the creator archetype, who succeeds by being 
imaginative and different (Mark \& Pearson, 2001). Through VNA, Figure 1 portrays the creator archetype in a story described by the protagonist and his relationship with the style of Versace, Hong Kong tailors, and David Bowie.

Figure 1 here.

The tailor from Hong Kong is a somewhat mysterious supporting actor in the story, as described in Part 1 of the VNA of this story. Who is this man who travels the world, produces in China and can produce products with such perfect style and size and such a reasonable price tag? The mystery further deepens by the whole process of having to track him down and make contact with him and the result of this consumer's "journey" (illustrated in Part 2 of the VNA). This result partly is due to the painstaking process of choosing the Versace fabrics and the language barriers that had to be overcome between the consumer and the tailor. Marquis orders three suits and four dress shirts. The final result, as shown in Part 3 of the VNA, reports the protagonist's feelings when he receives his order and culminates in happiness and a feeling of creative power, reaching its zenith in the last photograph in which Marquis wears his new suit, showing a perfect match with his original style and personality.

In his story, the consumer places emphasis on style and self-expression throughout the text, using references (David Bowie, Armani and Versace) that represent originality of style and inspiration (Wertime, 2002). David Bowie represents the creative archetype, constantly reinventing himself at every stage of his career and breaking the mold. The consumer's reaction to the arrival of his first order is the very experience of the archetype. Wearing new clothes, Marquis poses for a photograph, showing his style and posing in a manner similar to his main reference, David Bowie.

Evaluating texts and legends regarding the creator, one reports that in order to secretly continue with his philandering, Zeus took many different forms including that of a flame of 
fire, shower of gold, a male companion, a swan and a white bull to bed and the women and goddesses of Aegina, Dana, Leda, and Europa, not to mention numerous others, including nymphs. The blog story of "Marquis" contains many explicit representations of the pattern of Zeus. The blog's protagonist aligns strongly with David Bowie commenting on his newly made shirts as "two of them are pure David Bowie" and above an image of David Bowie awkwardly poised in an ill-fitting suit the protagonist expresses, "Oh my god. It was ALMOST my dream cut, but even I realize my dream cut is a bit impractical because you can't really move in it". The importance of the protagonist thinking about David Bowie reinforces the different forms of Zeus. David Bowie made famous the song Changes by emphasizing the many faces of his adopted characters including (but not limited to) Aladdin Sane, Detective Professor Adler, Jareth, The Man Who-Sold-the World, The Earthling, The Elephant Man, The Thin White Duke, and Ziggy Stardust (Buckley, 2001).

Furthermore, analyzing the profile of the author of this blog, the protagonist embraces at least three known forms as Marquis Déjà Dû, marquised and the real persona Todd Perley, "a Musician, Painter, Bohemian Layabout" according to his twitter profile. The Zeus thunderbolts as extensions of self and a sign of masculinity are analogous to the classical piano playing of Todd captured on the blog site as video shows the protagonist's hands scaling up and down the piano keys with great dexterity. The tailor embodies the powerful creator, the Versace brand appears as a tool and inspiration during the story and all three (the tailor, the Versace brand and David Bowie) result in the consumer himself, who choses and idealizes the products, experiencing the creator archetype, which allows a vision to take shape and create a self-expressive and lasting value (Mark \& Pearson, 2001). These conclusions reflect a very intense relationship between the consumer and the brands and elements found in his story. On the one hand, Versace and David Bowie are good examples of symbols in the plot that the consumer appreciates, involving the creator archetype, and on the other hand these brands project him into living this role. 


\section{EXAMPLE 2: THE SAGE ARCHETYPE}

In philosophy, human experience includes an intellectual dimension that objectifies the truth (Morris, 1997). The sage reflects this thirst for knowledge because this figure uses intelligence to understand the world (Mark \& Pearson, 2001) and represents a universal message of experience, counseling and heritage (Wertime, 2002).

The Wise Old Man is among the archetypes that appear more regularly in the analyses of youth, who names this theme and that of the hero as two of the most well-known (Jung, 1959, p. 285). Campbell (1968) provides a clear theme of guides/mentors, those who know secret paths and words of power and that this theme appears from the days of tribal medicine men until today, with modern doctors. Researchers examining this theme in fairytales and in the movies and find this archetype appearing in all those characters who teach and protect heroes and pass their teachings on to them, such as God walking in the Garden of Eden, Merlin providing guidance to King Arthur, the Fairy Godmother helping Cinderella, Alfred the butler in Batman, the spymaster M giving advice to James Bond, and Obi-Wan Kenobi in Star Wars (Wertime, 2002; Vogler, 2007). They help to enrich and open the eyes and mind of heroes or groups of people, who begin reflecting on what they have learned.

The function in the context of Campbell (1968): to help the hero during his trials and tribulations during his adventures. Advice is the sage's weapon. Using advice helps the hero to guide and aid others in their time of need or to provide them with personal growth and to improve their skills (Wertime, 2002). The consumer sees the sage in brands that promote expertise and information or which encourage clients to think and improve themselves (Mark \& Pearson, 2001). The consumer experiences this role when he offers advice and feels happy with the experience and expertise he garners on a given subject. Vogler (2007) mentions that in stories the archetype is flexible and that the function of teaching or giving something to someone who needs help, the hero in this case, can be temporarily or promptly performed even by a character that plays a different role, such as the hero himself, the trickster or even 
the villain. Vogler (2007, p. 46) also claims that the sage does not necessarily have to be old as such; indeed, "the young, in their innocence, are often wise and capable of teaching the old". Therefore, consumers from all walks-of-life experience democratic roles in their daily lives, according to their life story and knowledge. According to Wertime (2002), a mentor exists in each of us because experience shapes wisdom and constructs credibility.

\section{Decoding the Second Story}

Appendix 3 describes a story in which Sage archetype components are observable. This text represents the emic interpretation and contains an entire blog story. Appendix 4 shows a prediction matrix of the sage archetype, developed using literature on the archetype (Mark \& Pearson, 2001; Ullman \& Reichenberg, 2003; Wertime, 2002). In this case as well, the sixteen statements of the Archetypal Story Pattern Instrument for the Sage confirm the presence of the Sage archetype in the story told by the consumer about the time he lived in Beijing.

Scott's story, written during his last moments in Beijing, touches on the sage in several passages and teachings, and recognizes that in the end Scott himself, after six months studying in China, has become a citizen of the world, with a broader view that goes beyond his native land. The VNA shows certain points of this experience and the people involved in the transformation of the protagonist appear in Figure 2.

Figure 2 here.

The story begins during the protagonist's final moments in Beijing before boarding the plane to return home. With his bags packed, Scott recalls songs and special moments during his stay in Beijing. The protagonist visits the Forbidden City and cheerfully recounts the experience and his surprise when he learns that a Starbucks exists in this extremely restricted area. The thirst for knowledge, a deep desire to seek for and find the truth and 
understand nuances reflect characteristics of the sage (Mark \& Pearson, 2001). Scott, the protagonist, declares that he is glad that he has now made contact with people from six different continents and that the world is getting smaller after his period of study and experiences. His visit to the Great Wall and his tragicomic journey there is a story that he is eagerly looking forward to telling his future grandchildren. Telling his story to his grandchildren in the future is a message of passing on his experiences, a universal perception of the sage archetype (Wertime, 2002).

The protagonist lists his supporters, mentors and allies during the journey of learning: the fun friend, parents and family members, the internet, the professors at the Chinese university, the American university and even his landlord. According to the protagonist, they all contribute to making his stay a worthwhile experience and help him become wiser and with greater knowledge of the world. The disciple has now "graduated" and thanks his masters for his journey into knowledge. A Sage, Scott ends the text by breaking a paradigm that he observes in American society and that can only be broken those who undertake a journey like his. Incorporating the voice of experience, he issues a warning: "take heed those who shun the rest of the world... we will reap what we sow". This transformation is possible because the sage also learns the hard way: by making mistakes and discovering what not to do (Wertime, 2002). The journey gives him a basis of credibility.

The story details a portrait of the constructed perception of what China and particularly Beijing have meant, in addition to other elements such as the universities in question, in the life of the protagonist, serving as a springboard to knowledge and internal experience and wisdom and unlimited visions. The individual positions the brand so that the relationship bears fruit and achievements, with genuine insights to help understand the potential of this brand and its impact on other consumers with similar profiles and ambitions. 
The present study employs psychological theory of archetypes and models to apply the theory empirically and interpret the resulting data by way of the degree of freedom model and visual narrative art. The study offers a way of analyzing the consumer-brand relationship by delineating an archetype enacted by the consumer during his personal narrative. This approach, despite considering universal themes, examine how individuals positions experiences and brands in their life story and allocate meaning to them. The consumer may assign different roles to the same brand depending on the contexts of given stories.

This view enriches the debate by Allen et al (2008) and Fournier, Solomon, and Englis (2008) concerning the changing paradigm in order to face the construction of a brand's meaning. Marketing professionals are not the only "creators" of a brand's meaning, nor are they solely responsible for constructing the favorable, strong, and unique characteristics of the brand in the mind of the consumer in order to stand out in the market (Keller, 1993). The new paradigm extends the idea of the co-creation of meaning, a theory that originates in McCracken (1986) meaning transfer model.

In addition to marketing professionals, the consumer-brand archetypal theory also includes two sources of co-creators of meaning: consumers and the cultural context. The archetype approach using this alternative of brand function in the lives of consumers is made valid by this new paradigm, in which collectively shared themes and personal ambitions impel the use of brands to achieve often unconscious goals. In this context, marketing systems, cultural traditions and individual differences live side by side, molding that which is relevant to the plot that the individual wishes to experience and in which role the brand should play therein.

The instruments used for the DFA in both archetypes under study were constructed based on the theory of the archetype in question and provide objective support to the study. For example, if we use the instrument that was created for the creator archetype (Appendix 2) and analyze the second story about Beijing (Appendix 3), 6 of the 16 statements are 
confirmed, that is, statements $3,6,11,12,13$ and 16 are confirmed; but this is a far lower number than in the first story, for which $100 \%$ of the statements are confirmed. When the procedure is reversed and we analyze the story of the Chinese tailor (Appendix 1) using the instrument constructed for the sage (Appendix 4), 10 of the 16 statements are confirmed, i.e., statements $1,2,4,5,6,8,11,12,14$ and 15 ; but this number is still lower than the $100 \%$ matching of the story about Beijing. Despite involving making judgments that might be considered subjective when analyzing patterns, the DFA is constructed with a basis in the objectivity available in the theory. The visual narrative art, which is also an interpretative approach that places emphasis on subjective experience, seeks through the story to obtain additional insights and delineate the story, visually reinforcing aspects of the causes, transformation or the effects of the consumer's story.

The theories/methods mixing the platforms of the psychology of archetypes, the DFA method and the visual narrative art method work as alternative approaches for interpreting the relationship of the consumer with brands, invoking stories in which the consumer (but not the brand) is the protagonist and using this role for a purpose or in the light of a specific episode. This procedure might be useful for future studies that wish to analyze the variety of relationships and meanings that brands assume in a certain context or consumer group. The method serves to analyze the evolution of this relationship longitudinally, should it be possible to track stories and episodes over time.

Managerially, this approach adds to the efforts of marketing professionals for accurately gauging the role of brands in the life of consumers, all the while recognizing the subjective nature of the object under study. The paradigm of co-creation of meaning permits tracking the brand's presence in a story told by the consumer; such tracking provides valuable insights regarding what is happening in consumer practice and the symbolic value of brand related actions for the consumer. 


\section{References}

Aaker, J. (1997). Dimensions of brand personality. Journal of Marketing Research, Vol. 34, pp. 347-357.

Ahuvia, A.C. (2005). Beyond the extended self: loved objects and consumers' identity narratives. Journal of Consumer Research, Vol. 32, No. 1, pp. 171-184.

Aggarwal, P. (2004). The effects of brand relationship norms on consumer attitudes and behavior. Journal of Consumer Research, Vol. 31, No. 1, pp. 87-101.

Allen, C.T., Fournier, S., \& Miller, F. (2008). Brands and their meaning makers. In Haugtvedt, C.P.; Herr, P.M. \& Kardes, F.R. Handbook in consumer psychology (pp. 781-822). New York: Taylor \& Francis Group.

Allison, R. I., \& Uhl, K. P. (1964). Influence of beer brand identification on taste perception. Journal of Marketing Research, Vol. 1, pp. 36-39.

Belk, R.W. (1988). Possessions and the extended self, Journal of Consumer Research, Vol. 15, No. 2, pp. 139-168.

Brasel, S.A. \& Gipps, J. (2011). Red Bull "Gives You Wings" for better or worse: A doubleedged impact of brand exposure on consumer performance. Journal of Consumer Psychology, Vol. 21, No. 1, pp. 57-64.

Breivik, E. \& Thorbjornsen, H. (2008). Consumer brand relationships: an investigation of two alternative models. Journal of the Academy of Marketing Science, Vol. 36, No. 4, pp. 443-472.

Bruner, J. (2004). Life as a narrative. Social Research, Vol. 71, pp. 691-710.

Bucley, D. (2001) Strange fascination: David Bowie: The definitive Story, Virgin Books.

Campbell, D.T. (1975). Degrees of freedom in the case study. Comparative Political Studies, Vol. 8, pp. 178-193.

Campbell, J. (1988). The power of myth, with Bill Moyers. New York: Doubleday.

Christensen, G.L., \& Olson, J.C. (2002). Mapping consumers' mental models with ZMET. Psychology \& Marketing, Vol. 19, No. 6, pp. 477-502.

Dijksterhuis, A., Smith, P. K., VanBaaren, R. B., \& Wigboldus, D. H. J. (2005). The unconscious consumer: Effects of environment on consumer behavior. Journal of Consumer Psychology, Vol. 15, No. 3, pp. 193-202.

Dichter E. (1960). The strategy of desire. London: TV Boardman.

Escalas, J.E., \& Bettman, J.R. (2000). Using narratives and autobiographical memories to discern motives. In The why of consumption: perspectives on consumer motives, goals, and desires. Ed. S. Ratneshwar, D. G. Mick and C. Huffman, New York: Routledge.

Escalas, J. E., \& Bettman, J.R. (2005). Self-Construal, Reference Groups, and Brand Meaning, Journal of Consumer Research, Vol. 32, No. 3, pp. 378-89.

Evans, J.S. (2008). Dual-processing accounts of reasoning, judgment and social recognition. Annual Review of Psychology, Vol. 59, pp. 255-78.

Faber, M.A., \& Mayer, J.D. Resonance to archetypes in media: There's some accounting for taste. Journal of Research in Personality, Vol. 43, No. 3, pp. 307-322.

Fournier, S. (1998). Consumers and their brands: Developing relationship theory in consumer research. Journal of Consumer Research, Vol. 24, No. 4, pp. 343-373.

Fournier, S. (2009). Lessons learned about consumers' relationships with their brands. In: MacInnins, D.; Park, C.W.; Priester, J.R. Handbook of brand relationships (pp. 5-23). M.E. Sharpe: New York, 2009.

Fournier, S.; Avery, J.\& Alvarez, C. (2012). A contracting framework for understanding consumers' relationships with brands. Paper presented at: Avery, J.; Breazeale, M.; Fetscherin, M.; Fournier, S. (orgs.) Consumer Brand Relationships 2012 Conference. Boston, MA. 
Fournier, S.; Solomon, M.R. \& Englis, B.G. (2008). When brands resonate. In: Schmitt, B.H. \& Rogers, D.L. (eds.) Handbook on brand and experience management. Northampton, MA: Edward Elgar Publishing Inc. pp. 35-57.

Hall, S. (1997). Introduction. In Representation: Cultural representations and signifying practices, edited by Stuart Hall. London: Sage. Hamilton, E. (1942). Mythology: Timeless tales of gods and heroes. London: Penguin Group.

Hirschman, E.C. (2010). Evolutionary branding. Psychology \& Marketing, Vol. 27, No. 6, pp. 568-583.

Holt, D.B. (2003). What becomes an icon most? Harvard Business Review, Vol. 81, No. 3, pp. 43-49.

Holt, D.B. (2004). How brand become icons: The principles of cultural branding. Boston: Harvard Business School Press.

Jung, C.G. (1959). The archetypes and the collective unconscious. New York: Pantheon Books.

Keller, K. L. (1993). Conceptualizing, measuring and managing customer-based brand equity. Journal of Marketing, Vol. 57, pp. 1-22.

Kervyn, N. Fiske, S.T., \& Malone, C. (2012). Brands as intentional agents framework: How perceived intentions and ability can map brand perception. Journal of Consumer Psychology, Vol. 22, No. 2, pp. 166-176.

McAdams, D.P. (1993). The stories we live by: Personal myths and the making of the self. New York: William Morrow and Company.

McCracken, G. (1986), Culture and consumption: a theoretical account of the structure and movement of the cultural meaning of consumer goods, Journal of Consumer Research, Vol. 13, pp. 71-84.

Mark, M., \& Pearson, C.S. (2001). The hero and the outlaw: building extraordinary brands through the power of archetypes. New York: McGraw-Hill.

Megehee C.M., \& Spake D.F. (2012), Consumer enactments of archetypes using luxury brands, Journal of Business Research, Vol. 65, No. 20, pp. 1434-1442.

Megehee, C. M., \& Woodside, A.G. (2010). Creating visual narrative art for decoding stories that consumers and brands tell. Psychology \& Marketing, Vol. 27, No. 6, pp. 603622.

Miller, F.M.; Fournier, S. \& Allen, C.T. (2012). Exploring relationship analogues in the brand space. In: Fournier, S.; Breazeale, M.; Fetscherin, M. Consumer-brand relationships: theory and practice. New York: Routledge.

Morris, T. (1997). If Aristotle ran General Motors: the new soul of business. New York, NY: Henry Holt and Company.

Park, C.W. (2012). What is JCP's next move? Journal of Consumer Psychology, Vol. 22, No. 4, pp. 471-472.

Pearson, C.S. (1998). The hero within: six archetypes we live by. New York: HarperCollins Publishers.

Polkinghorne, D.E. (1991). Narrative and self-concept. Journal of Narrative and Life History, Vol. 1, No. 2-3, pp. 135-153.

Schank, R.C. (1995). Tell me a story. Evanston, IL: Northwestern University Press.

Schank, R.C. \& Abelson, R.P. (1995). Knowledge and Memory: the real story. In: Wyer, R.S. (ed.) Knowledge and memory: the real story. Hillsdale, NJ: Lawrence Erlbaum Associates (pp. 1-85).

Solomon, M.R. (2013). Consumer behavior. New Jersey: Pearson.

Swaminathan, V. \& Dommer, S.L. (2012). When is our connection to brands like our connection to people? Differentiating between consumer-brand relationships and 
interpersonal relationships. In: Fournier, S.; Breazeale, M.; Fetscherin, M. Consumerbrand relationships: theory and practice. New York: Routledge, pp. 15-29.

Ullman, R., \& Reichenberg-Ullman, J. (2001). Mystics, masters, saints, and sages: Stories of enlightenment. Berkeley, CA: Conari Press.

Veen, S.V. (1994). The consumption of heroes and the hero hierarchy of effects. In Advances in Consumer Research, Vol. 21, pp. 332-336. Eds. Chris T. Allen and Deborah Roedder John, Provo, UT.

Vincent, L. (2002). Legendary Brand: unleashing the power of storytelling to create a winning market strategy. Kaplan Business: Chicago.

Vogler, C. (2007). The writer's journey: Mythic structure for writers. Studio City, CA: Michael Wiese Productions.

Wertime, K. (2002). Building brands \& believers: how to connect with consumers using archetypes. Singapore: Wiley.

Woodside, A.G. (2004). Advancing from subjective to confirmatory personal introspection in consumer research. Psychology \& Marketing, Vol. 21, No. 12, pp. 987-1010.

Woodside, A.G. (2008). Using the forced metaphor-elicitation technique (FMET) to meet animal companions within self. Journal of Business Research, Vol. 61, No. 5, pp. 280287.

Woodside, A.G. (2010). Case study research: theory, methods and practice. Bingley: Emerald.

Woodside, A.G., Sood, S., \& Miller, K.E. (2008). When consumers and brand talk: storytelling theory and research in psychology and marketing. Psychology \& Marketing, Vol. 25, No. 2, pp. 97-145.

Woodside, A.G., Megehee, C.M., \& Sood, S. (2011). Conversations with(in) the collective unconscious by consumers, brands and relevant others. Journal of Business Research, Vol. 65, No. 5, pp. 594-602.

Zaltman, G. (2003). How consumers think: essential insights into the mind of the marketer. Boston: Harvard Business School Press.

Zehnder, S.M., \& Calvert, S.L. (2004). Between the hero and the shadow: developmental differences in adolescents' perceptions and understanding of mythic themes in film. Journal of Communication Inquiry, Vol. 28, No. 2, pp. 122-137. 


\section{Appendix 1 - Emic Interpretation of Versace by Marquis Déjà Dû}

Once upon a time, I was walking through a casino in Vegas with my friend when I noticed the really nice cut of his suit. "Where did you get that?" I asked, having tried on numerous suits trying to get just that effect. Just for fun, I've tried on $\$ 4000$ Armani suits, and while they're better, less boxy than Fat American Tailored Clothes, it still wasn't quite right. "This guy in Hong Kong. He travels the world. You catch him in a city, look at the thousands of fabric swatches laid out on the hotel bed, and then he measures you, makes the clothes in China for a fraction of the price it would cost here, then ships them to you."

I've been trying to hook up with this guy for almost two years. I extended my El Uh trip by a day when I was out there recently so I could catch him on his Beverley Hills date. That tells you how much I wanted to meet him; I willfully stayed in California 24 hours more than necessary.

My friend Patrick, out there from Brooklyn, went with me, thinking he might have a dress shirt made. We both spent about three hours looking through the fabric choices, and I ended up getting THREE suits and FOUR dress shirts, and even Patrick ended up with a suit and a few shirts. Today, the first one arrived, with one of the shirts. This was the "normal" one. (Two of them are pure David Bowie.) The "normal" one I kinda went out on a limb for, shelling out some extra $\$ \$ \$$ for the fabric I wanted, which is a beautiful Versace fabric with subtle, eroded, muted gold stripes.

The shirt that arrived is a thin striped pattern. I unwrapped the clothes, worried that nothing would fit. I mean, the Hong Kong guy knows what he's doing, but I was making special requests for how I like MY clothes to fit, which is not really standard in the world of suits. "Contoured. Fitted. Supertailored. Think Gaultier. Think corseted." I wasn't sure how much was getting through since there was a bit of a language barrier.

I put the shirt on first and squealed like a little girl.

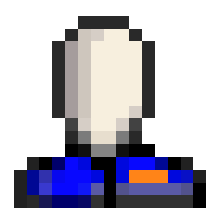

Matel and I went shopping at \$ak's a few weeks ago. I had a pile of about ten dress shirts I wanted to try on. Only two fit the way I like them to, and these are $\$ 250$ shirts (at \$ak's, that is. Liz had a $25 \%$ off coupon and I had gift cards, so really it was "free", but you get the point - if you can't find what you want at high end stores, you tend to think it doesn't exist). But this shirt — ahhhh — my words did get through to Mr. Hong Kong. It was like the shirt was made exactly for me. Which, in fact, it was, but I was beyond pleased with the cut, and the delicious length of the sleeves (my arms are 6' long), and the yummy French cuffs. I don't have enough clothes to wear with which I can utilize my collection of really cool cufflinks.

Then the pants. Again: perfection. Not just in the waist and leg length (my legs are 27' long), but the whole baggy/saggy ass thing which sometimes happens with suit pants because I don't have a hot black man's bubble butt - was not an issue. It was like wearing a second skin. I remember sucking in my gut when he was measuring me because I planned on losing more weight. Which I have, and so the pants are perfect.

Then the coup de grace - the coat, for it's the coat that makes the suit.

Oh my god. It was ALMOST my dream cut, but even I realize my dream cut is a bit impractical because you can't really move in it: 


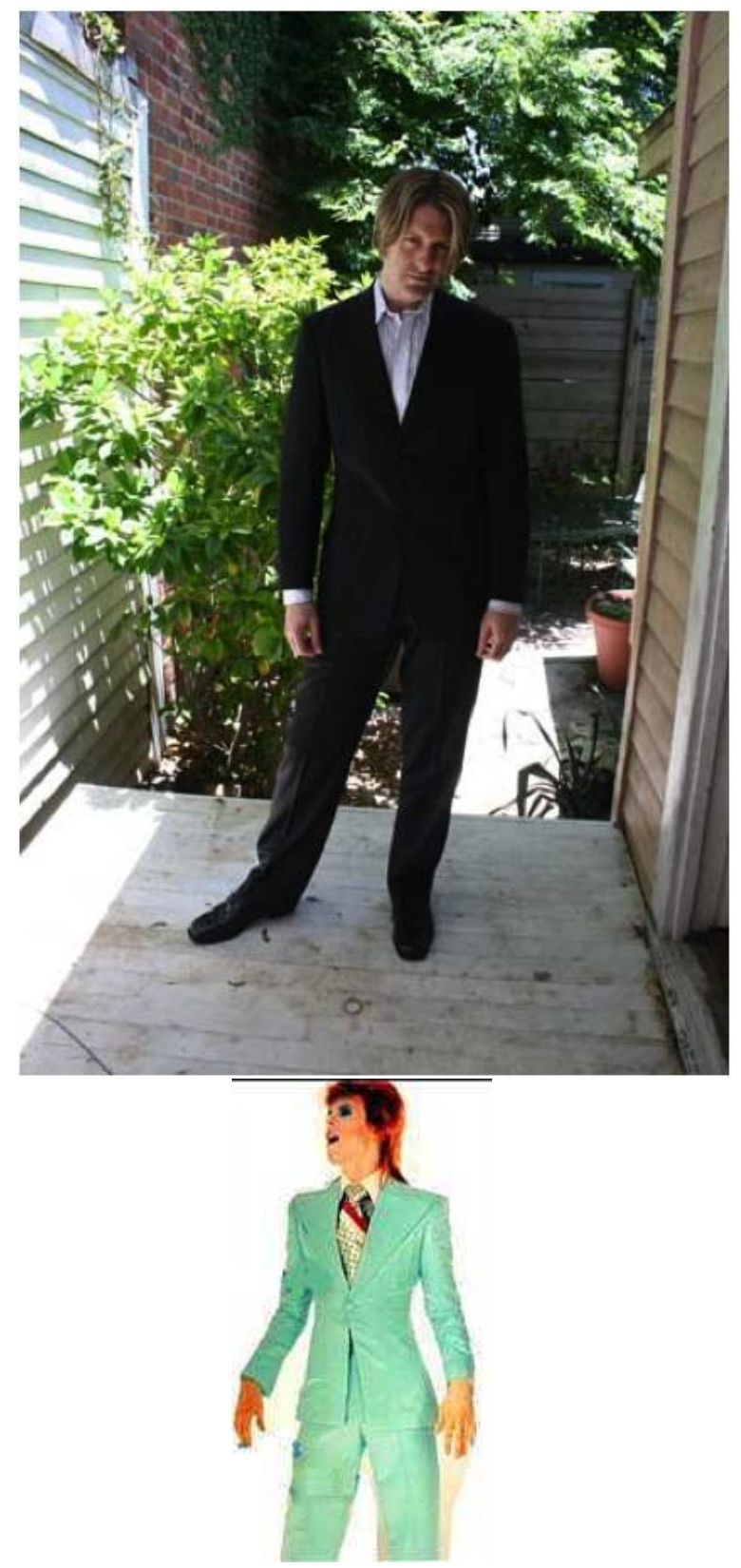

So, there it is. A $\$ 4,500$ custom tailored Versace suit for ... considerably less. God bless sweat shops and favorable exchange rates. (The pattern of the suit is too subtle for the glaring afternoon light in this photo.)

Can't wait for my rockstar stuff to show up! 


\section{Appendix 2 Creator Archetype for Tailor Ho!}

\section{Creator (CR) - Archetypal Story Pattern Instrument}

Blog: It's $\cdot$ not $\cdot$ the $\cdot$ fall $\cdot$ that $\cdot$ kills $\cdot$ you, $\cdot$ but $\cdot$ the $\cdot$ sudden $\cdot$ stop.

Title of Blog Entry: Tailor-Ho!

Please circle $\mathbf{N}=$ No; $?$ = Not sure; $\mathrm{Y}=$ Yes for each item below.

1. Is the protagonist creating something new? $\quad \mathrm{N} \quad ? \quad \mathrm{Y}$

If yes, discuss evidence: Describes a suit and dress shirts he wants from Hong Kong tailor

2. Protagonist is using creativity or imagination? N ? $\quad \mathrm{Y}$

Evidence: Imagery of David Bowie to describe cut of his suit. Also, an investment of 3-4 hours choosing fabric.

3. Is the story about overcoming boring or routine work? $\mathrm{N}$ ?

Evidence: Focus of story and self-modeling photograph at end is entirely about ordering custom shirts and suit.

4. Does the protagonist helping others to reignite the passion within? $\mathrm{N}$ ? $\mathrm{Y}$

Evidence: His friend Patrick seems very involved judging by his time commitment.

5. Is the protagonist offering friendship? $\mathrm{N} \quad ? \quad \mathrm{Y}$

Evidence: The context of the blog supporting the story and ability to send a virtual gift suggests friendship to be a distinct possibility.

6. The story relates to lots of ideas? $\quad \mathrm{N} \quad \mathrm{Y}$

Evidence: Discussion of everything from cuff links to meeting with friends

7. The protagonist is skillful? $\mathrm{N} \quad$ ? $\mathrm{Y}$

Evidence: Protagonist has a keen dress sense and spends on dress shirts and without saying negotiated a good price for his custom clothing.

8. Does the protagonist have a vivid imagination? $\mathrm{N} ? \mathrm{Y}$

Evidence: His reference to David Bowie and his awaiting of "rock stuff" as well as cool cuff links, "Think Gaultier. Think corseted" and on wearing pants "It was like wearing a second skin" all add up to well-developed imagination supported with a descriptive vocabulary.

9. The protagonist follows a predetermined direction? $\quad \mathrm{N} \quad ? \quad \mathrm{Y}$ Evidence: The blog story focus is entirely on his purchase from a Hong Kong tailor.

10. Alignment with stories of other inventors, artists or entrepreneurs? N ? Y

Evidence: Strong references to David Bowie and Hong Kong Tailor as a super tailor.

11. Does the story highlight the protagonist's aesthetic sense? $\mathrm{N}$ ? $\mathrm{Y}$

Evidence: The entire story alludes to dress sense and beautiful clothes. 
12. Avoidance of the mundane? $\mathrm{N}$ ? $\mathrm{Y}$

Evidence: Story only covers travel and fashion without reference to work.

13. The protagonist is critical of herself and others? $\quad \mathrm{N} \quad ? \quad \mathrm{Y}$

Evidence: Every aspect of the protagonist commentary is a critique from packaging to the fitting of clothes.

14. Is co-creation of artefacts an important aspect of the storyline? $\quad \mathrm{N} \quad ? \quad \mathrm{Y}$

Evidence: The protagonist is a co-creator of the suit and shirts having spent 3 to 4 hours with friend choosing fabrics, colors and designs.

15. Any areas where the story illustrates following intuition? $\mathrm{N}$ ? $\mathrm{Y}$

Evidence: Placing the order alone with the Hong Kong tailor is a move based on intuition.

16. Any sign of the protagonist following her dream? $\quad \mathrm{N} \quad$ ? Y

Evidence: The dream associates with David Bowie a rock legend from 1970s and is always changing his clothes, appearance and even cross-dressing. David Bowie developed Ziggy Stardust an alter ego.

\section{Appendix 3 - Emic Interpretation of Scott Farewell to Beijing} Wednesday, December 22, 2004, Farewell Beijing

I just finished packing, each bag bursting with goodness. Nostalgic songs have given way to Rick James and a more celebratory mood. Today I went to the Forbidden City for the first time, and couldn't have picked a better day. 28 degrees F, snow...perfect outdoor touring conditions. As I approached the gate 2 friends of mine from school had the same idea. Gordon and Charlie are both from Beijing and couldn't wait for the first snow to see the Forbidden City again. We all toured around taking pictures. Although I didn't see it, apparently there is a Starbucks IN the Forbidden City...unreal. I did manage to buy a great hat that all the soldiers wear in winter time and got a few cool pics.

What can I say? This has been the time of my life. I went out with a bunch of foreign exchange students last night for duck, and we all toasted to the good times here, and had a few laughs over some classic stories. At that moment I realized that I now have friends on 6 continents. That pretty much covers them all, until I meet a nice Antarctican. The world just got a whole lot smaller to me... a place where opportunity is boundless, or bounded only by the limitations of the mind.

I have seen things I have only dreamed of. I recall driving to the Great Wall for the first time. The driver was flying around turns with reckless abandon. In my heart I felt that if I was going to go flying off this cliff, it better be AFTER I see the Great Wall. I did see it, and it blew me away, and for a brief second on the way home I thought "okay, now you can drive like a nut." On second thought, never mind, I've got grandkids to tell these stories to one day.

And now, I venture home. One semester left at Pepperdine, and its back to the real world again. Only I have a great feeling the real world is going to be a lot more unreal than I ever imagine.

Finally a special thanks to my parents for making all of this possible. They are the absolute best people on the planet, for if they weren't my parents, I'd be the luckiest person in the world to have them as friends. They were with me every step of the way. And to my friends and family who kept me up on all of the happenings back home, and who I sorely 
missed as time went on here. Your contact made me feel like I was never that far away. -the internet...I couldn't have done it without you. A special note to Justin Andersen, my old roommate (AKA the Other Worst Guy). Your stories and comments to this blog were absolutely out of control. So funny. Looking forward to seeing you again...WEEEEEEEE!! -Pepperdine University -Graziadio School of Business, this opportunity has been so incredible. I knew coming back to school was going to change my life...but I had no idea. And to Ming, my landlord: You will probably won't be able to read this without breaking some kind of law, but all of your help has been greatly appreciated. And to my Tsinghua professors: You all seemed patient to open my eyes to China and its inner workings. You gave me a view of a future, globalization that I finally understood.

On a final note, I realize something that perhaps is only possible by traveling or living abroad. America is not the center of the universe. It is utterly important, no doubt, but the world is coming up, and the playing field will even out in my lifetime. Take heed those who shun the rest of the world...we will reap what we sow. On that note...I've got a plane to catch! (Source: http://china-monologues.blogspot.com/2004/12/farewell-beijing_22.html)

\section{Appendix 4 - Sage Archetype for Farewell Beijing Sage (SA) - Archetypal Story Pattern Instrument \\ Blog: The China Monologues \\ Title of Blog Entry: Farewell Beijing}

Please circle $\mathrm{N}=$ No; $\quad ?=$ Not sure; $\mathrm{Y}=$ Yes for each item below .

1. Does the story invoke an old man or women? N ? Y

Evidence: Scott expresses his mad ride to the great Wall as “...I've got grandkids to tell these stories to one day".

2. Does protagonist research and think through her problems? N ? Y

Evidence: Sharing thinking on the business concepts of globalization does suggest Scott is capable of research and deep thinking.

3. Reference to academia? $\mathrm{N} \quad$ ?

Evidence: Scott is in final semester of Graduate School of Business.

4. Does the story cover a long-range perspective? N ? Y

Evidence: Nearing conclusion of his story Scott raises the importance of US not being at the center of all activities "... and the playing field will even out in my lifetime."

5. Is the protagonist seeking truth? $\mathrm{N} \quad ? \quad \mathrm{Y}$

Evidence: In his summary Scott affirms, “...take heed those who shun the rest of the world...we will reap what we sow." This thinking points to a desire to seek truth.

6. Protagonist has an area of expertise? $\mathrm{N} \quad \mathrm{Y}$

Evidence: In his limited time in China Scott indicates to his professors “...you all seemed patient to open my eyes to China and its inner workings. You gave me a view of a future, globalization that I finally understood".

7. Is the story objective? $\mathrm{N} \quad$ ?

Evidence: The story is a balance of Scott's learnings and own experiences while in Beijing. 
8. Reading the story a sense of teaching or mentoring? N ? $\quad \mathrm{Y}$ Evidence: The story provides a sense of teaching.

9. Is the protagonist always calm? $\mathrm{N} \quad$ ?

Evidence: Scott appears to have remained calm in the "mad driving" to the Great Wall.

10. Does the story suggest an ivory tower mentality? N ? $\quad \mathrm{Y}$

Evidence: In a way the conclusion or teaching Scott shares with readers is idealistic and missing the integration of some real world issues.

11. Advice given? $\mathrm{N} \quad$ ? $\mathrm{Y}$

Evidence: Absolutely, Scott provides his view of globalization and America in his lifetime no longer being in a central position of power.

12. Protagonist is foreigner or different culture/age? N ? $\quad \mathrm{Y}$

Evidence: Scott is visiting China from America for one semester.

13. Is deep thinking/intelligence essential to follow story? $\mathrm{N} \quad ? \quad \mathrm{Y}$

Evidence: Useful but probably not essential.

14. Protagonist plans decisions? N ? $\quad \mathrm{Y}$

Evidence: Not enough decision making witnessed to provide an answer.

15. Areas where story involves technology or complexity? N ? $\mathrm{N}$

Evidence: As a farewell, the story does not involve many difficulties for an English reader. However, readers may find an understanding of globalization helps weigh the comments Scott makes at the end.

16. Any sign of people asking protagonist for advice? N ? $\quad \mathrm{Y}$

Evidence: The blog story will precipitate advice seeking but nothing in the story illustrates the advice giving capability of the protagonist. 


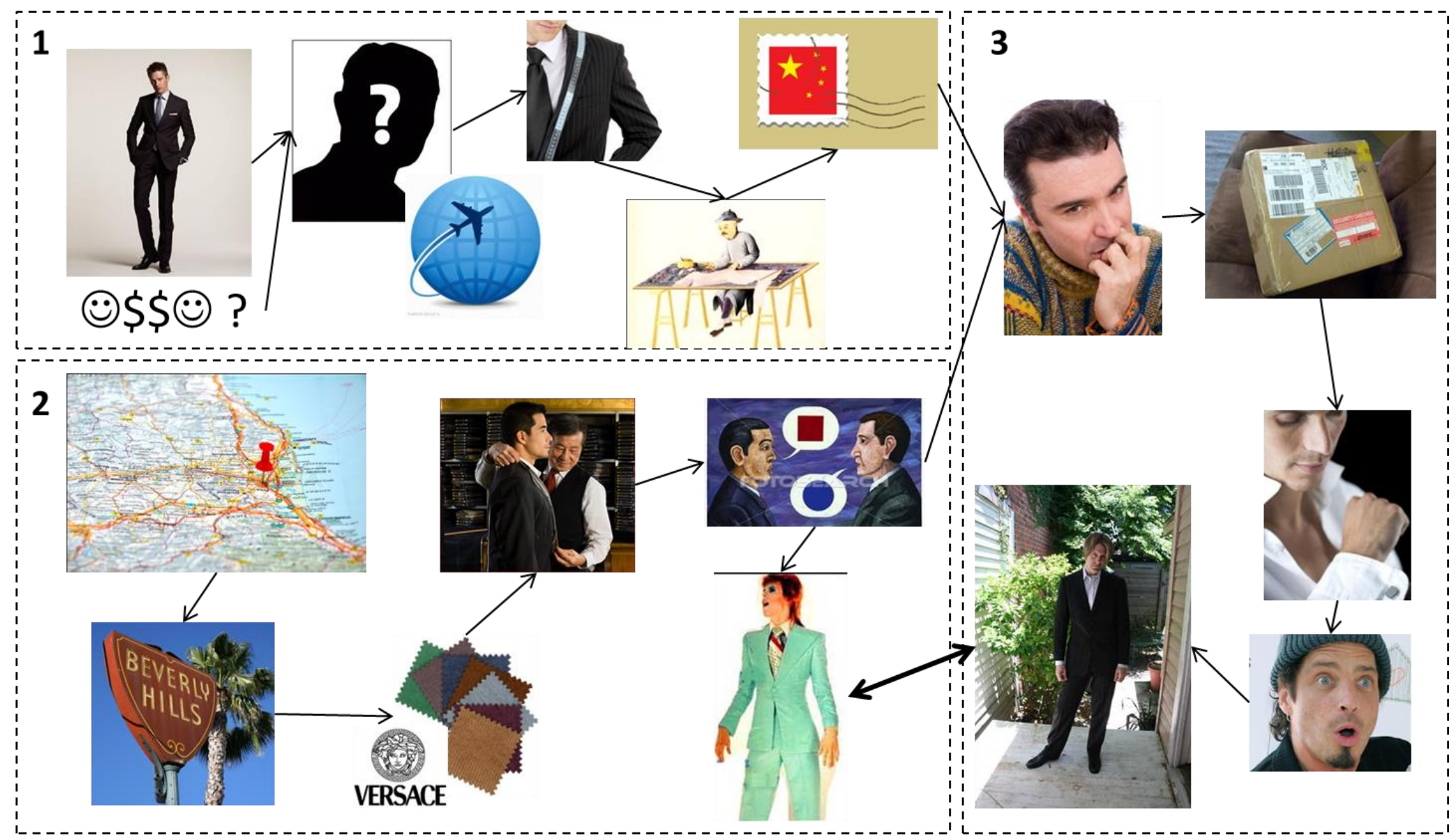

Figure 1. Visual Narrative Art of the Creator archetype in the Versace tailor-made suit.

1) The consumer sees his friend's nice suit and discovers he paid a fraction of the price a good one would cost in the USA. The friend told him about the tailor from Hong Kong, who travels the world, and if you catch him, you can choose from thousands of types of fabric. Your body is measured, and the tailor will make the clothes and ship them to you from China.

2) After two years tracking him down, the consumer catches up with him in Beverley Hills, goes through this process, chooses a Versace fabric, and, despite the language barrier, describes what he wants, in the dynamic and creative style of David Bowie, whom he admires.

3) The consumer is worried about the final product when the package arrives from China, and after trying on the shirt and suit he is thrilled and feels powerful with the new clothes. 


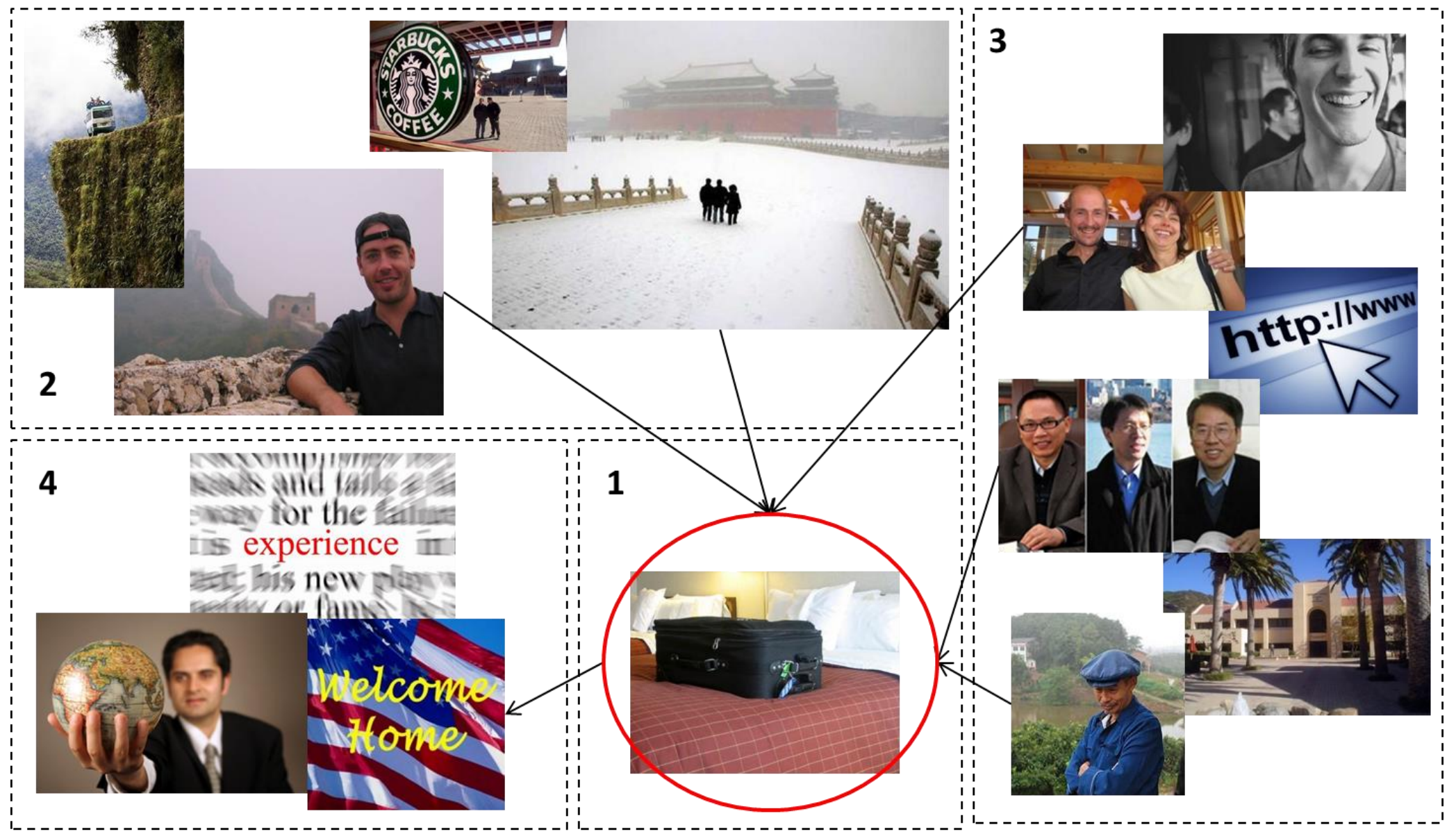

Figure 2. Visual Narrative Art of the Sage archetype founded in the Farewell Beijing Blog Story

1) The protagonist's case is packed and "bursting with goodness". The story kicks off full of nostalgia and reports the transformation of the protagonist while in Beijing;

2) The experiences of the final days in China and its nuances: the visit to the Great Wall (and the tragicomic journey to get there) and the visit to the forbidden city (with descriptions of the snow, the friends who were there and the surreal scene of a Starbucks there);

3) Thanks to the people who supported him and taught him something have transformed the protagonist; the fun friend, parents and family members, the internet, professors, the American university that made it all possible and his landlord.

4) The protagonist feels wiser after his trip, a citizen of the world with a broad vision, willing to teach what he has learned. 